\title{
Effect of Metal Barrier Layer for Flexible Solar Cell Devices on Stainless Steel Substrates
}

\author{
Kyoung-Bo Kim* \\ Department of Metallurgical \& Materials Engineering, Inha Technical College 100 Inha-Ro Nam-Gu, Incheon, South Korea $402-752$
}

Received November 23, 2016; revised December 15, 2016; accepted December 16, 2016

\begin{abstract}
A thin metal layer of molybdenum is placed between the conventional barrier layer and the stainless steel substrate for investigating the diffusion property of iron $(\mathrm{Fe})$ atoms. In this study, the protection probability was confirmed by measuring the concentration of out-diffused Fe using a SIMS depth profile. The Fe concentration of chromium (Cr) barrier layer with $10 \mathrm{~nm}$ molybdenum (Mo) layer is 5 times lower than that of $\mathrm{Cr}$ barrier without the thin Mo layer. The insertion of a thin Mo metal layer between the barrier layer and the stainless steel substrate effectively protects the out-diffusion of Fe atoms.
\end{abstract}

Keywords: Diffusion Barrier, Multilayer, Flexible Solar Cell, Stainless Steel

\section{Introduction}

Most available solar modules are fabricated on rigid glass or crystalline silicon substrates. However, the advantages of thin film solar cells are their low thickness and lightweight compared to crystalline silicon solar cell, which enables making flexible solar modules. These offer the opportunity to decrease the production cost over general processes using rigid substrates. The most crucial factor to accomplishment of flexible solar module production is the development of flexible substrates [1-3]. Stainless steel (STS) and polymer substrates are commonly used for flexible substrates in roll to roll processes [4-6]. STS substrates have many advantages such as chemical stability and lower thermal expansion coefficient compared to polymer substrates. In addition, a high temperature process is possible due to higher thermal stability of STS than that of a polymer, and a passivation layer is not needed to prevent water vapor and oxygen through the substrate. However, impurities from the substrate are an issue for electronic applications. The device performance can be significantly reduced by the out-diffusion of detrimental element from STS substrate such as iron (Fe) or chromium (Cr) atoms [7]. Therefore, these types of impurities must be decreased for application in electronic devices. The outdiffusion of impurities is an especially critical problem because the deposition of copper indium gallium diselenide (CIGS) thin film is performed at over $550^{\circ} \mathrm{C}$ substrate temperature using a co-evaporation method [8]. If monolithic integration technology of the solar cell devices

*Corresponding author

E-mail: kbkim@inhatc.ac.kr is applied for fabricating solar modules on electrically conducting substrates, the deposition of a dielectric barrier is necessary for insulation and diffusion barrier $[9,10]$. Thin $\mathrm{Cr}$ layers [11] as well as dielectric layers like $\mathrm{Al}_{2} \mathrm{O}_{3}$ $[9,12]$ or $\mathrm{SiO}_{2}[12]$ have been used as diffusion barriers. However, conventional monolithic processes are not suited for the production of solar modules using roll-to-roll techniques owing to the technology limitation such as patterning. Hence, the flexible solar cell modules are manufactured by inter-connection of cells which have

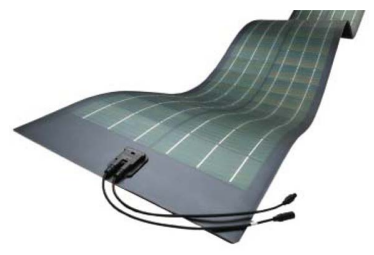

(a)

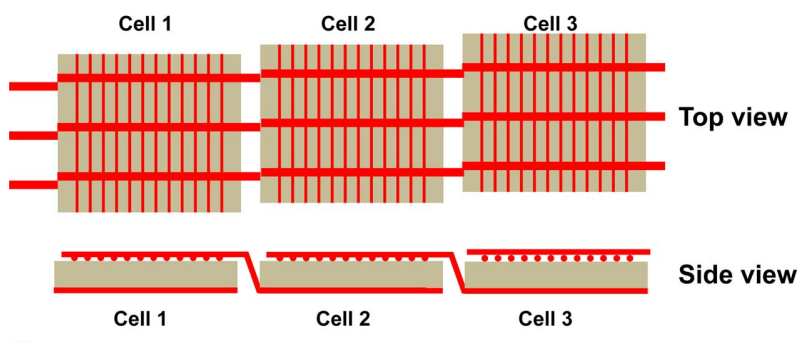
(b)

Figure 1. Example of flexible solar cell module of (a) PowerFLEXTM (Global solar company, http://www.globalsolar. $\mathrm{com} /$ ) and (b) Schematics of inter-connection of cells as the identical method of crystalline silicone solar modules fabrication, which needs metallic barrier on electrically conducting substrates to flow the current cell to cell. 


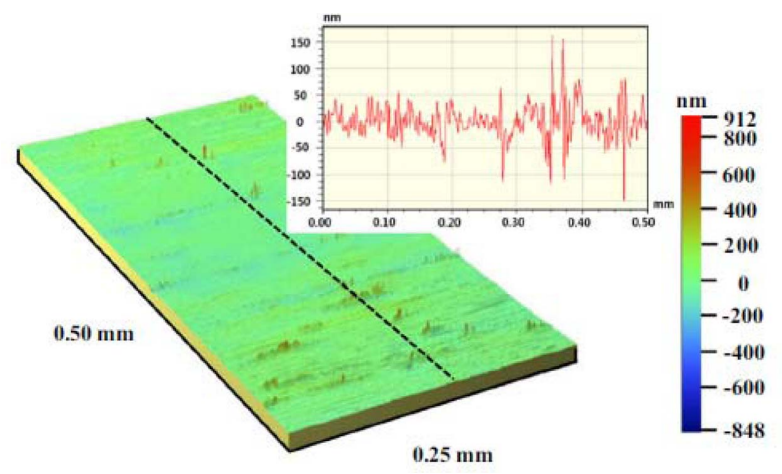

Figure 2. 3D surface profile images in a scanning area of $0.5 \times 0.25 \mathrm{~mm}^{2}$ with respect to the STS substrate.

electrically conducting barriers such as $\mathrm{Cr}$ layer on substrate, as shown in Figure 1. The properties of metallic barrier are very important to determining the solar cell performance. In this work, we investigated the $\mathrm{Cr}$ and $\mathrm{Cr}$ / Molybdenum (Mo) barrier layers to prevent the diffusion of impurities from the STS substrates.

\section{Experiments}

The STS (Cr steel) with a thickness of $127 \mu \mathrm{m}$, which is already commercialized for thin film solar cell by POSCO, was used as a substrate because the thermal expansion of $\mathrm{Cr}$ steel is lower than that of nickel (Ni)-Cr steel [8]. The solar grade of $\mathrm{Cr}$ steel also has a much finer surface compared to conventional $\mathrm{Cr}$ and $\mathrm{Ni}-\mathrm{Cr}$ steel. The surface roughness values of the STS substrate measured by 3D surface profiler are $\mathrm{Ra} 41.5 \mathrm{~nm}$ and $\mathrm{Rz} 297.6 \mathrm{~nm}$, respectively (Figure 2). First, the STS substrates, which have no surface polishing treatment for the confirmation of commercial use, were prepared for the deposition of barrier layers by cleaning organic contaminations using acetic acid and deionized water. Next, the pre-treatment of radio frequency (RF) plasma was used for improving the adhesion of deposited films on the STS substrate. The plasma pre-treatment was conducted at RF power of $80 \mathrm{~W}$ and pressure of 800 mTorr using Ar flow, and then a metal layer was deposited by using sputter. The sputtering condition was direct control power of $300 \mathrm{~W}$ for Cr layer and $800 \mathrm{~W}$ for Mo layer during Ar gas flow. To examine the out-diffusion phenomena of impurities from the STS substrate, a rapid thermal annealing (RTA) was processed at $600^{\circ} \mathrm{C}$ and $60 \mathrm{~min}$ under a fixed total pressure of 10 mTorr. In this work, we attempted to analyze the structure of barrier layers by using various analytical tools such as transmission electron microscopy (TEM), energy dispersive spectroscopy (EDS), and secondary ion mass spectroscopy (SIMS).

\section{Results and Discussion}

Figure 3 shows the schematic diagram of the structures of barrier layer. The detailed thickness of each layer is described in Table 1. We adopted a thin Mo interlayer between the $\mathrm{Cr}$ layer and STS substrate for effectively inhibiting the out-diffusion of impurities like $\mathrm{Fe}$ atoms from STS substrate. Figure 4 shows cross sectional TEM images and EDS elemental mapping profiles for the sample \#1 (Cr/STS) and \#2 (Cr/Mo/STS), respectively. We cannot found the crack in the barrier layer and adhesion

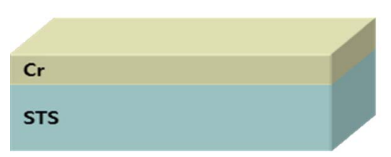

(a)

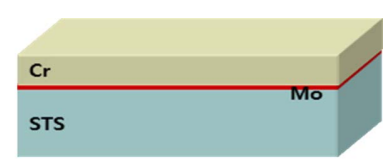

(b)
Figure 3. Schematics of various barrier layers of (a) Cr/STS and (b) $\mathrm{Cr} / \mathrm{Mo} / \mathrm{STS}$.

Table 1. Layer thickness of various barrier layers.

\begin{tabular}{ccccc}
\hline \hline Sample \# & Materials & $\begin{array}{c}\text { Layer } \\
\text { thickness } \\
(\mathrm{nm})\end{array}$ & $\begin{array}{c}\text { Coating } \\
\text { techniques }\end{array}$ & RTA \\
\hline 1 & $\mathrm{Cr} / \mathrm{STS}$ & 100 & Sputter & \\
2 & $\mathrm{Cr} / \mathrm{Mo} /$ & $100 / 10$ & $\begin{array}{c}\text { Sputter/ } \\
\text { Sputter }\end{array}$ & $600^{\circ} \mathrm{C}$ \\
\hline
\end{tabular}
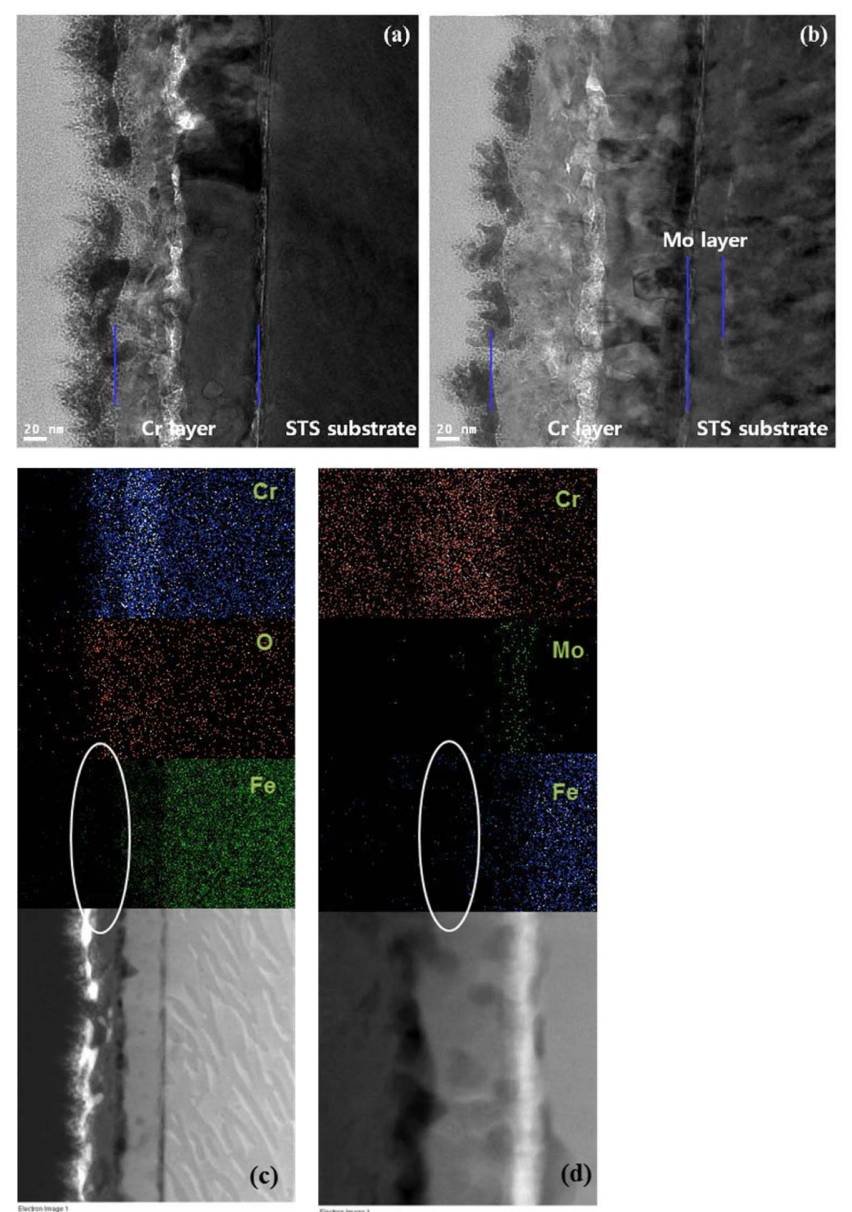

Figure 4. Cross sectional TEM of (a) \#1 Cr/STS and (b) \#2 Cr/ Mo/STS, and EDS elemental mapping profile for the sample (c) \#1 Cr/STS and (d) \#2 Cr/Mo/STS. 


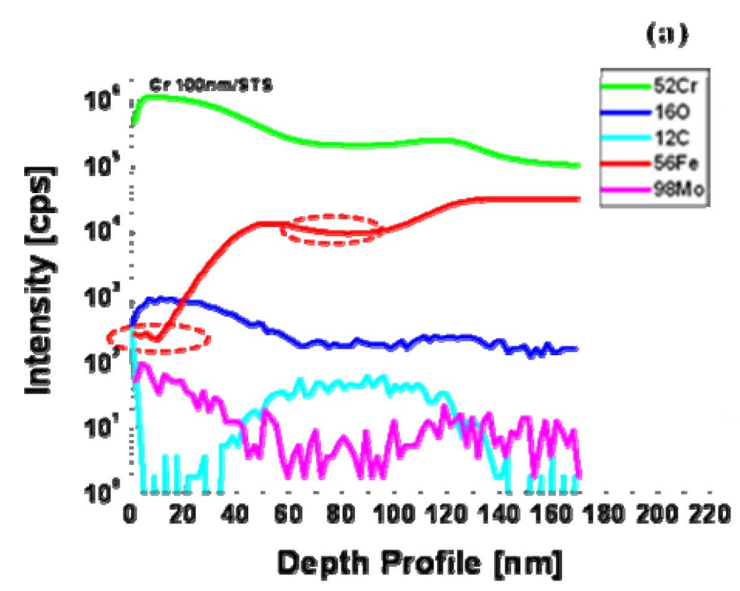

(b)

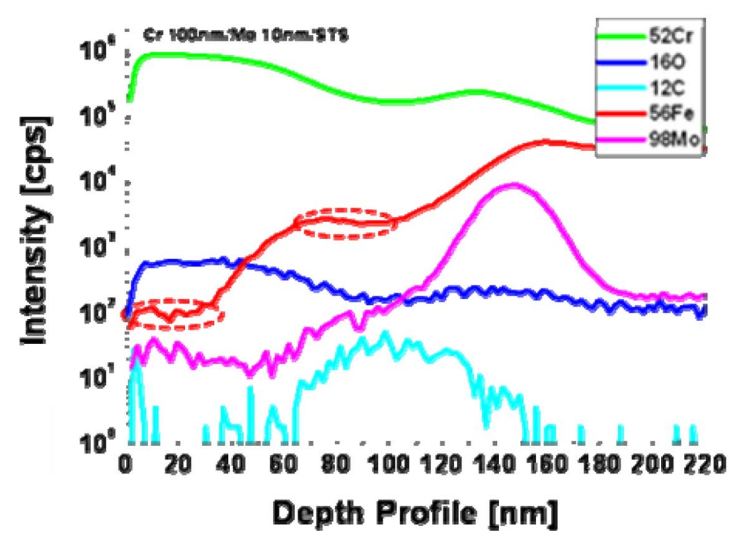

Figure 5. SIMS depth profiles of (a) \#1 $\mathrm{Cr} / \mathrm{STS}$ and (b) \#2 Cr/ Mo/STS.

failure at the interface between substrate and barrier layer. In the case of insulating barrier layers, the crack and adhesion failure can be appeared in the thin film solar cells fabricating on metal substrate by thermal processing due to the thermal expansion coefficient difference of each layer [13]. This means that the mechanical properties of metallic barriers are very useful for making flexible thin film solar cells using metallic substrate. It can be also found that the concentration of $\mathrm{Fe}$ atoms decreases when moving from substrate to surface and is nearly undetectable at the surface from the EDS data, as shown in Figure 4(c) and (d). Fe impurities in both $\# 1$ and $\# 2$ samples were fully protected by the $\mathrm{Cr}$ barrier layer. $\mathrm{Cr}$ layers in both $\# 1$ and \#2 are separated into two layers after the RTA heat treatment. The separation of $\mathrm{Cr}$ layers might be related to the out-diffusion of $\mathrm{Fe}$ because the concentration of $\mathrm{Fe}$ was decreased toward the surface. Therefore, it is postulated that the Fe concentration is different in the divided layers. A SIMS analysis was used to determine the exact $\mathrm{Fe}$ concentration (relative intensity (counts per second, CPS) of each element in (a) $\mathrm{Cr} / \mathrm{STS}$ and (b) $\mathrm{Cr} / \mathrm{Mo} / \mathrm{STS}$ before quantification using reference sample) within the barrier layers. Figure 5 shows the SIMS depth profiles of sample $\# 1$ and \#2 after the RTA process. It was observed that the concentration of $\mathrm{Fe}$ had a step profile to the depth direction. From these results, the phenomenon of $\mathrm{Cr}$ layer separation can be easily explained by the different concentration of $\mathrm{Fe}$ in both \#1 and \#2. It can be also found that the Fe concentration in first step region near the STS substrate at \#1(Cr/Mo/STS $)$ is much lower than that of \#2 $(\mathrm{Cr} / \mathrm{STS})$. Finally, the surface $\mathrm{Fe}$ concentration of \#1 sample is about 5 times lower than that of $\# 2$ because the thin Mo layer has a role to effectively protect the outdiffusion of $\mathrm{Fe}$ atoms. Therefore, the insertion of a thin metal layer including a Mo layer between $\mathrm{Cr}$ barrier and stainless steel substrate is an effective method for reducing the out-diffusion of Fe atoms. The STS substrate with $\mathrm{Cr}$ and Mo barrier layers is useful for the reduction of $\mathrm{Fe}$ in active films for electronic device performance.

\section{Summary}

This study shows that a thin metal layer insertion between a conventional barrier layer and a stainless steel substrate effectively protected the diffusion of impurities. We found that the $\mathrm{Fe}$ concentration of the $\mathrm{Cr}$ barrier layer with $10 \mathrm{~nm}$ Mo layer is 5 times lower than that of the $\mathrm{Cr}$ barrier without thin a Mo layer. A multilayered barrier is more effective than a single layered barrier because the existence of interfaces between the barrier and substrate is able to hinder the out-diffusion of Fe to the surface. It is presumed that a constant trend is obtained, similar to the case of Mo for other metals.

\section{Acknowledgments}

This work was supported by 2016 INHA TECHNICAL COLLEGE Research Grant.

\section{References}

[1] Blösch, D. Güttler, A. Chirila, and A.N. Tiwari, Thin Solid Films 519,7453 (2011).

[2] J. Perrenoud, B. Schaffner, S. Buecheler and A. N. Tiwari, Solar Energy Materials \& Solar Cells 95, S8 (2011).

[3] J. Moon, D. -J. Park, C. H. Chung, Y. -H. Kim, S. J. Yun, J.W. Lim, J.-H. Lee, Mater. Res. Soc. Symp. Proc. 910, 0910-A18-03 (2006).

[4] Otte, L. Makhova, A. Braun, and I. Konovalov, Thin Solid Films 511-512, 613 (2006).

[5] F. Kessler, D. Herrmann, and M. Powalla, Thin Solid Films 480, 491 (2005).

[6] B. B. Van Aken, C. Devilee, M. Dörenkämper, M. Geusebroek, M.C.R. Heijna, J. Löffler, and W. J. Soppe, Journal of NonCrystalline Solids 354, 2392 (2008).

[7] K. Herz, A. Eicke, F. Kessler, R. W achter, and M. Powalla, Thin Solid Films 431-432, 392 (2003)

[8] R. Wuerz, A. Eicke, M. Frankenfeld, F. Kessler, M. Powalla, P. Rogin, and O. Yazdani-Assl, Thin Solid Films 517, 2415 (2009).

[9] F. Kessler, K. Herz, M. Powalla, M. Hartmann, M. Schmidt, A. Jasanek, and H. W. Schock, Proceeding Vol. 668 of the Mat. Res. Soc. Symp., San Francisco, 2001, p. H3.6.1.

[10] K. Herz, F. Kessler, R. Wächter, M. Powalla, J. Schneider, A. Schulz, and U. Schumacher, Thin Solid Films 403-404, 384 (2002).

[11] M. Hartmann, M. Schmidt, A. Jasenek, H.-W. Schock, F. Kessler, K. Herz, and M. Powalla, Proceedings of the 28th IEEE Phot. 
Spec. Conf., Anchorage, 2000, p. 638.

[12] G. S. Vicente, J. Herrero, A. Morales, C. Mafiotte, M. T. Gutierrez, M. Hartmann, A. Jasenek, and H. W. Schock, Proceedings of the 17th Eur. Phot. Sol. Conf., Munich, 2001, p. 1098.

[13] D. Amouzou, J. Dumont, L. Fourdrinier, J. Richir, F. Maseri, and R. Sporken, Thin Solid Films 531, 535 (2013). 